\title{
PREDIKTOR INTENSI PENGGUNAAN INTERNET DALAM MELAKUKAN PEMBELIAN ONLINE
}

\author{
Yeti Diah Wiyanti \& Wisnu Untoro \\ Universitas Sebelas Maret Surakarta, Indonesia \\ Email: yetidiahwiyanti@gmail.com
}

\begin{abstract}
Abstrak: Prediktor Intensi Penggunaan Internet dalam Melakukan Pembelian Online. Tujuan penelitian ini adalah untuk menguji dan menganalisis pengaruh niat konsumen dalam menggunakan internet untuk melakukan pembelian online. Sebuah metodologi survei digunakan untuk mengumpulkan data 160 orang mahasiswa pengguna internet di Universitas Sebelas Maret Surakarta yang pernah melakukan pembelian online. Analisis SEM menunjukkan bahwa faktor-faktor penentu niat berupa: sikap, norma subjektif, kontrol perilaku yang dirasakan dan kepercayaan berpengaruh signifikan pada intensi penggunaan internet untuk melakukan pembelian kecuali pengalaman belanja online tidak berpengaruh signifikan terhadap intensi penggunaan internet untuk melakukan pembelian dan faktor-faktor penentu niat berupa: sikap, norma subjektif, kontrol perilaku yang dirasakan, pengalaman belanja online dan kepercayaan berpengaruh signifikan terhadap intensi penggunaan internet untuk melakukan pembelian ketika dimoderasi oleh intensi penggunaan internet untuk pencarian informasi.
\end{abstract}

Kata kunci: Theory of Planned Behavior (TPB), pengalaman belanja online, kepercayaan, intensi penggunaan internet.

\begin{abstract}
Predictors of The Intention to Use The Internet for Purchasing. The purpose of this study was to examine and analyze the influence of intention to use the internet for purchasing. A survey methodology used to data from 160 Internet users students at the Sebelas Maret University which ever purchase online. SEM analysis show that the determinants of intention form: attitude, subjective norms, perceived behavioral control and trust have a significant effects on the intention to use the internet for purchasing unless the internet purchase experience have no significant effect on the intention to use the internet for purchasing and the determinants of intention form of: attitude, subjective norm, perceived behavioral control, internet purchase experience, and trust have a significant effects on the intention to use the internet for purchasing when moderated by the intention to use the Internet for information search.
\end{abstract}

Keywords: Theory of Planned Behavior (TPB), internet purchase experience, trust, intention to use the internet.

\section{PENDAHULUAN}

Saat ini, internet menjadi salah satu alat komunikasi yang utama dan internet juga merupakan sarana elektronik yang dapat digunakan untuk berbagai aktivitas seperti komunikasi, pencarian informasi, transaksi bisnis dan lainnya. Penggunaan internet pada kegiatan bisnis dapat meningkatkan penjualan dan mengurangi biaya serta dapat mewujudkan keunggulan kompetitif (Yannopoulos, 2011).

Seiring berjalannya waktu, pengguna internet semakin meningkat dari tahun ke tahun. Menurut lembaga riset pasar e- 
Marketer, Indonesia menduduki peringkat ke- 6 dalam hal penggunaan internet dengan jumlah pengguna mencapai 83,7 juta orang di tahun 2014. Hal tersebut diperkirakan akan terus meningkat hingga mencapai 112 juta orang di tahun 2017, mengalahkan Jepang di peringkat ke-5 yang pertumbuhan jumlah pengguna internetnya lebih lamban (tekno.kompas.com, 2014).

Berdasarkan hasil survei yang dilakukan oleh Kemenkominfo dan UNICEF tahun 2014 menunjukkan bahwa pengguna internet dikalangan anak-anak dan remaja mencapai 79,5\% dengan motif untuk jejaring sosial, pencarian informasi dan hiburan (apjii.or.id, 2014), sehingga media sosial telah menjadi alat yang sangat penting dalam penyebaran informasi yang efektif bagi remaja (Hayta, 2013). Menurut kelompok organisasi Perserikatan Bangsa-Bangsa yang dimaksud remaja adalah sekelompok konsumen yang berusia antara 15-24 tahun (undesadspd.org), dan banyaknya penelitian yang telah dilakukan adalah untuk memprediksi atau mengantisipasi perilaku remaja (Murad dan Salleh, 2014), karena remaja memiliki peran yang sangat penting dalam melaksanakan pencarian informasi maupun pembelian online.

Salah satu yang menjadi alasan konsumen tertarik untuk melakukan transaksi online adalah kenyamanan yang diberikan oleh pedagang online kepada konsumen, diantaranya konsumen tidak dihadapkan pada permasalahan kemacetan lalu lintas, waktu, parkir, dan lain-lain (Yulihasri et al., 2011). Konsumen juga dapat berbelanja sepanjang hari selama 24 jam, sehingga konsumen dapat membeli barangbarang dan jasa kapan saja dan dimana saja, selain itu konsumen juga dapat memenuhi keinginannya hanya dengan melakukan transaksi melalui internet dan tanpa keluar rumah (Jusoh dan Ling, 2012).

Kenyamanan yang diberikan pada konsumen seharusnya mampu meningkatkan penjualan online, tetapi adanya risiko yang menimbulkan kekhawatiran bagi para pelaku belanja online menjadikan jumlah konsumen yang melakukan pembelian online justru masih relatif sedikit (Rianto, Lumanto, dan Meiningsih, 2013). Fenomena tersebut memberikan dampak bagi konsumen, seperti seringnya konsumen menggunakan internet hanya untuk mencari informasi produk saja (Shim, Eastlick, Lotz, dan 2001). Pencarian informasi tersebut sangat penting dilakukan agar konsumen memiliki bekal informasi yang cukup sebelum melakukan pembelian online dan tidak merasa kecewa setelah melakukan pembelian online. Menurut Shim et al. (2001) pencarian informasi dapat meningkatkan niat konsumen dalam menggunakan internet untuk melakukan pembelian secara online, sehingga semakin sering konsumen melakukan pencarian informasi produk maka keinginan konsumen untuk melakukan pembelian online akan semakin meningkat. Hal ini berarti bahwa variabel intensi penggunaan internet untuk pencarian informasi merupakan variabel pemoderasi.

Pencarian informasi merupakan fungsi yang paling penting dalam melakukan pembelian melalui internet, sehingga berperan penting dalam memprediksi keinginan konsumen dalam melakukan pembelian di masa mendatang (Shim et al., 2001). Keinginan tersebut berdasar pada 
keyakinan yang dimiliki individu berdasarkan pada pengalaman masa lalu. Keyakinan berdasarkan pada pengalaman masa lalu tersebut terkait dengan perilaku tertentu, informasi yang bersumber dari pengamatan dan dari orang lain tentang suatu perilaku, dan faktor-faktor tertentu yang dapat mempengaruhi individu dalam melakukan suatu perilaku (Ajzen, 1991). Pengalaman belanja melalui internet akan menurunkan risiko dalam belanja melalui internet sehingga akan meningkatkan intensi pembelian yang lebih besar melalui internet (Dai, Forsythe, dan Kwon, 2014).

Keamanan menjadi bagian penting dari transaksi online. Javadi, Dolatabadi, Nourbakhsh, Poursaeedi, dan Asaddollahi (2012) dalam penelitiannya menegaskan bahwa risiko keuangan dan risiko diluarpengiriman memiliki efek negatif pada sikap terhadap perilaku berbelanja secara online. Penjual online harus dapat meyakinkan pembeli bahwa situsnya aman, serta harus meyakinkan pelanggan tentang jaminan keamanan dalam pengiriman produknya. Penelitian ini juga menunjukan bahwa variabel sikap dan norma subyektif memiliki kontribusi yang besar dalam berbelanja online. Inovasi terhadap domain memiliki dampak yang positif terhadap perilaku berbelanja online. Ini berarti penjual online harus merumuskan strategi pemasarannya untuk meningkatkan efektifitasnya.

Sikap merupakan evaluasi positif atau negatif individu terhadap perilaku tertentu, dan norma subjektif merupakan persepsi seseorang terhadap tekanan sosial untuk melakukan atau tidak melakukan perilaku tertentu (Fishbein dan Ajzen, 1975), sedangkan kontrol perilaku yang dirasakan merupakan persepsi individu terhadap kontrol yang dimilikinya sehubungan dengan perilaku tertentu (Ajzen, 1991). Faktor ini menurut Ajzen (1991) mengacu pada persepsi individu mengenai mudah atau sulitnya memunculkan tingkah laku tertentu dan diasumsikan merupakan refleksi dari pengalaman di masa lalu dan juga hambatan yang diantisipasi. Menurut Ajzen (1991) ketiga faktor ini yaitu sikap, norma subyektif, dan kontrol perilaku yang dirasakan dapat memprediksi intensi individu dalam melakukan perilaku tertentu.

Dai, et al. (2014) dalam penelitiannya mengemukakan bahwa pengalaman belanja melalui internet akan menurunkan risiko dalam belanja melalui internet sehingga akan meningkatkan intensi pembelian yang lebih besar melalui internet. $\mathrm{Hal}$ tersebut diperkuat oleh penelitian dari Forsythe dan Shi (2003) yang menunjukkan bahwa pengalaman positif dalam berbelanja secara online mempengaruhi persepsi dan intensi pembeli dalam berbelanja secara online.

Kepercayaan juga menjadi bagian dari perilaku konsumen untuk melakukan pembelian secara online. Niat dorongan pembelian, orientasi kualitas, orientasi merek, kepercayaan online dan pengalaman pembelian online sebelumnya memiliki pengaruh yang positif terhadap niat pembelian konsumen secara online (Ling, Chai, dan Piew, 2010). Kepercayaan juga memiliki peran penting dalam mempengaruhi perilaku seseorang untuk berbelanja secara online, sehingga dalam penelitian ini menggunakan tujuh variabel yaitu: sikap, norma subjektif, kontrol perilaku yang dirasakan, pengalaman berbelanja online, kepercayaan, intensi penggunaan 


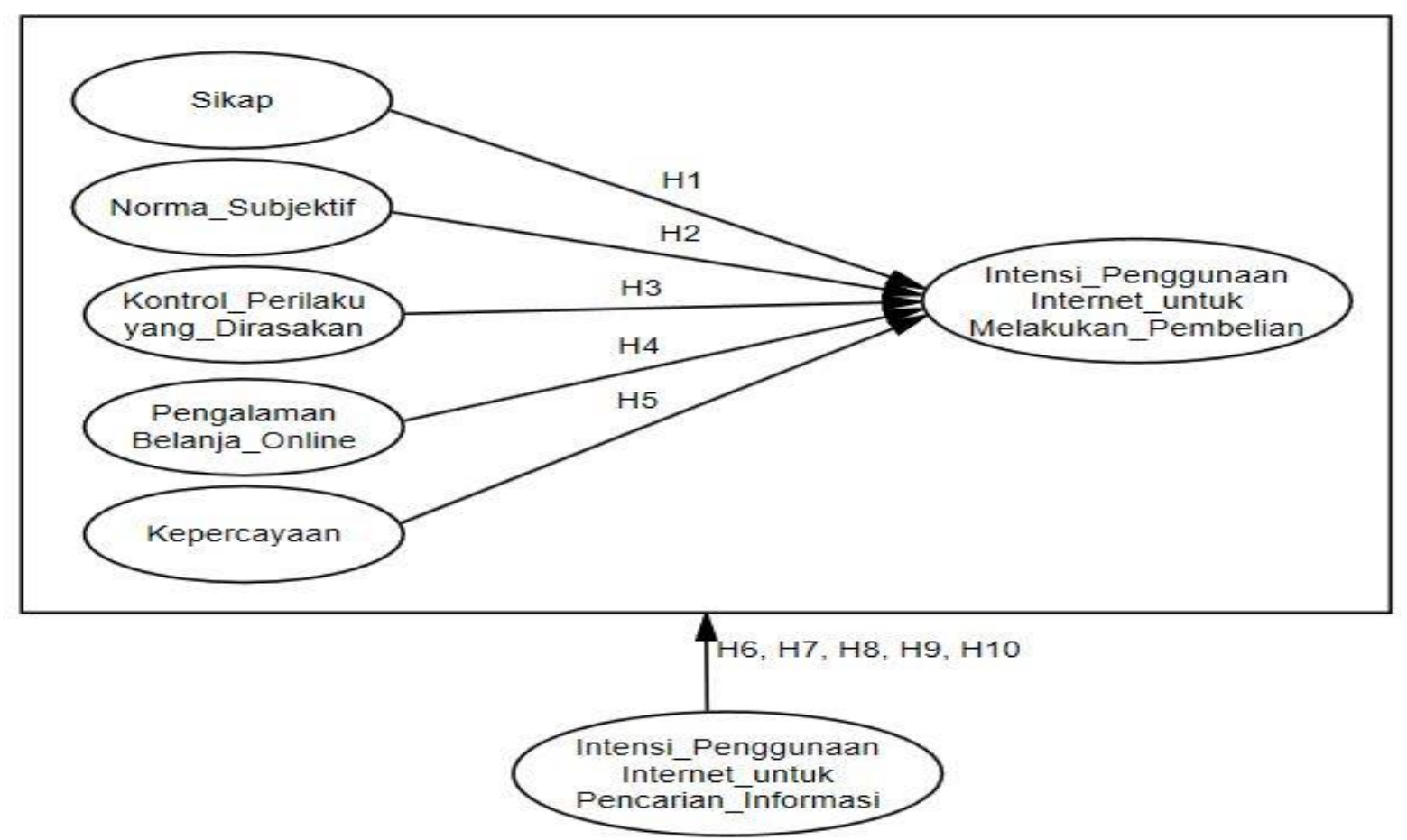

Gambar 1. Kerangka Pemikiran (dimodifikasi dari model penelitian Shim et al. (2001); dan Ling et al., 2010)

internet untuk pencarian informasi, dan intensi penggunaan internet untuk melakukan pembelian secara online.

Berdasarkan permasalahan dan teori tersebut, penulis tertarik untuk melakukan penelitian dengan judul "Prediktor-Prediktor Intensi Penggunaan Internet dalam Melakukan Pembelian Online".

\section{METODE}

Penelitian ini dikategorikan sebagai penelitian survei. Variabel yang digunakan dalam penelitian ini adalah sikap, norma subjektif, kontrol perilaku yang dirasakan, pengalaman belanja online, kepercayaan, intensi penggunaan internet untuk pencarian informasi, dan intensi penggunaan internet untuk melakukan pembelian. Kerangka pemikiran dalam penelitian tertuang dalam Gambar 1.

Berdasarkan dugaan sementara bahwa sikap berpengaruh pada intensi penggunaan internet untuk melakukan pembelian (Shim et al., 2001), norma subjektif berpengaruh pada intensi atau niat (Yulihasri et al., 2011), kontrol perilaku yang dirasakan berpengaruh pada intensi penggunaan internet untuk melakukan pembelian (Shim et al., 2001), pengalaman belanja online berpengaruh pada intensi penggunaan internet untuk melakukan pembelian (Shim et al., 2001; dan Kim et al., 2004), Kepercayaan berpengaruh pada intensi / niat (Liu et al., 2005), sikap berpengaruh pada intensi penggunaan internet untuk melakukan pembelian dimoderasi oleh intensi penggunaan internet untuk pencarian informasi, norma subjektif berpengaruh pada intensi penggunaan internet untuk melakukan pembelian dimoderasi oleh intensi penggunaan internet untuk pencarian informasi, kontrol perilaku yang dirasakan berpengaruh pada intensi penggunaan internet untuk melakukan pembelian dimoderasi oleh intensi 
penggunaan internet untuk pencarian informasi, pengalaman belanja online berpengaruh pada intensi penggunaan internet untuk melakukan pembelian dimoderasi oleh intensi penggunaan internet untuk pencarian informasi, dan kepercayaan berpengaruh pada intensi penggunaan internet untuk melakukan pembelian dimoderasi oleh intensi penggunaan internet untuk pencarian informasi, maka hipotesis yang diajukan dalam penelitian ini adalah sebagai berikut:

H1 : Sikap berpengaruh signifikan terhadap intensi penggunaan internet untuk melakukan pembelian

H2 : Norma subjektif berpengaruh signifikan terhadap intensi penggunaan internet untuk melakukan pembelian

H3 : Kontrol perilaku yang dirasakan berpengaruh signifikan terhadap intensi penggunaan internet untuk melakukan pembelian

H4 : Pengalaman belanja online berpengaruh signifikan terhadap intensi penggunaan internet untuk melakukan pembelian

H5 : Kepercayaan berpengaruh signifikan terhadap intensi penggunaan internet untuk melakukan pembelian

H6 : Sikap berpengaruh signifikan terhadap intensi penggunaan internet untuk melakukan pembelian yang dimoderasi oleh intensi penggunaan internet untuk pencarian informasi

$\mathrm{H} 7$ : Norma subjektif berpengaruh signifikan terhadap intensi penggunaan internet untuk melakukan pembelian yang dimoderasi oleh intensi penggunaan internet untuk pencarian informasi
H8 : Kontrol perilaku yang dirasakan berpengaruh signifikan terhadap intensi penggunaan internet untuk melakukan pembelian yang dimoderasi oleh intensi penggunaan internet untuk pencarian informasi

H9 : Pengalaman belanja online berpengaruh signifikan terhadap intensi penggunaan internet untuk melakukan pembelian yang dimoderasi oleh intensi penggunaan internet untuk pencarian informasi

$\mathrm{H} 10$ : Kepercayaan berpengaruh signifikan terhadap intensi penggunaan internet untuk melakukan pembelian yang dimoderasi oleh intensi penggunaan internet untuk pencarian informasi

Sampel yang digunakan dalam penelitian ini adalah 5 kali parameter yang diestimasi dengan parameter sebanyak 32, sehingga didapat ukuran sampel sebanyak 160 . Teknik pengumpulan sampel dalam penelitian ini menggunakan teknik nonprobability sampling (pengambilan sampel secara tidak acak) dengan cara quota sampling yakni cara pengambilan sampel di mana jumlah responden yang akan diteliti ditetapkan terlebih dahulu baru kemudian siapa yang akan dipilih menjadi anggota sampel terserah peneliti (Sanusi, 2011).

Instrumen penelitian untuk pengumpulan data dalam penelitian ini menggunakan kuesioner. Uji instrumen penelitian meliputi uji validitas dan uji reliabilitas. Uji validitas menggunakan teknik Confirmatory Factor Analysis (CFA) dengan bantuan AMOS 23. Standar loading estimate yang digunakan pada masing-masing item pertanyaan dalam penelitian ini adalah $\geq 0,50$ (Ghozali, 2008). Uji reliabilitas menggunakan 
Tabel 1. Hasil Pengujian Goodness of Fit Model

\begin{tabular}{lccc}
\hline \multicolumn{1}{c}{ Goodness-of-fit-indices } & Cut-off Value & Hasil & Kesimpulan \\
\hline Chi-Square & Diharapkan kecil & 342,207 & Diharapkan kecil \\
Degree Of Freedom & Positif & 338 & Fit \\
Chi Square probability $(\mathrm{p})$ & $\geq 0,05$ & 0,426 & Fit \\
CMIN/DF & $\leq 2$ & 1,012 & Fit \\
GFI & $\geq 0.90$ & 0,872 & Marjinal \\
AGFI & $\geq 0.90$ & 0,836 & Marjinal \\
IFI & $>0.90$ & 0,998 & Fit \\
TLI & $>0.90$ & 0,998 & Fit \\
CFI & $>0.90$ & 0,998 & Fit \\
RMSEA & $\leq 0.05$ & 0,009 & Fit \\
\hline
\end{tabular}

cronbach alpha sebesar 0,7 (Ghozali, 2008). Teknik analisis data menggunakan Structural Equation Modelling (SEM). Indeks kesesuaian model Goodness of fit yang digunakan dalam penelitian ini menggunakan referensi dari Ferdinand (2002).

\section{HASIL DAN PEMBAHASAN}

Penelitian ini menggunakan Structural Equation Modelling (SEM) dengan bantuan program AMOS 23. Hal-hal yang diperhatikan dalam melakukan pengujian dengan pendekatan Structural Equation Modelling (SEM) yaitu asumsi model, analisis kesesuaian model dan analisis Structural Equation Modelling (SEM).

Penelitian ini menggunakan uji normalitas untuk mengetahui apakah data berdistribusi normal ataukah tidak. Evaluasi normalitas diidentifikasi baik secara univariate maupun multivariate. Nilai critical ratio (c.r.) skewness value dan kurtosis value menunjukkan bahwa data tidak normal secara univariate karena memiliki nilai critical ratio (c.r.) skewness value dan kurtosis value $>2,58$, sehingga untuk memperbaiki data yang tidak normal secara univariate maka dilakukan transformasi data agar tidak menghasilkan nilai bias dan dapat menghasilkan data yang normal secara univariate. Pengujian normalitas secara multivariate menunjukkan nilai $<7$ yang menandakan bahwa data dalam penelitian ini berdistribusi normal secara multivariate.

Uji terhadap multivariate outliers dilakukan dengan menggunakan kriteria jarak mahalanobis pada tingkat $p<0,001$. Jarak mahalanobis tersebut dievaluasi dengan menggunakan nilai chi-square $\left(\chi^{2}\right)$ pada derajat bebas sejumlah variabel indikator yang digunakan dalam penelitian (Ghozali, 2008). Penelitian ini menggunakan 32 indikator variabel. Jarak Mahalanobis yang lebih besar dari $\chi^{2}(32 ; 0,001)=62,487$ adalah multivariate outlier. Pada tabel 14 diatas terlihat bahwa semua observasi memiliki jarak mahalanobis $<62,487$, sehingga dapat disimpulkan bahwa dalam penelitian ini tidak terdapat outlier.

Pengujian model fit ini diperoleh nilai $\chi^{2}$ dengan tingkat signifikansi lebih besar dari 0,05 dengan nilai $\chi^{2}$ sebesar 342,207 
menunjukkan bahwa model penelitian yang diajukan sudah memenuhi. Nilai CMIN/DF, GFI, AGFI, TLI, CFI, dan RMSEA dalam model penelitian ini menunjukkan tingkat kesesuaian yang baik.

Hasil pengujian hipotesis sebelum dimoderasi oleh intensi penggunaan internet untuk pencarian informasi menunjukkan bahwa dari 5 jalur yang dianalisis hanya terdapat 4 hipotesis yang memiliki hubungan signifikan, terlihat dari besarnya tingkat signifikansi (p) hasil uji hipotesis dari 2 variabel yang kurang dari $5 \%$ dan hasil uji hipotesis dari 2 variabel yang kurang dari $10 \%$. Hasil uji hipotesis setelah dimoderasi oleh intensi penggunaan internet untuk melakukan pencarian informasi menunjukkan hasil bahwa nilai chi square tabel $(\chi 2)>$ selisih chi square hitung $(\Delta \chi 2)$ sehingga model constrained secara signifikan berbeda dengan model unconstrained.

Berdasarkan Tabel 2 hasil uji hipotesis sebelum adanya moderasi, maka didapatkan hasil pembahasan uji hipotesis sebagai berikut:
1. Ada hubungan yang signifikan antara sikap dan intensi penggunaan internet untuk melakukan pembelian $(\beta=-0,160$ atau bernilai negatif; S.E. =0,094; C.R. = 1,705 ) atau $P=0,088<0,10$. Temuan ini menjelaskan bahwa semakin rendah sikap individu maka akan semakin tinggi intensi penggunaan internet untuk melakukan pembelian yang dilakukan oleh individu tersebut. Dengan demikian hipotesis yang menyatakan bahwa sikap berpengaruh signifikan terhadap intensi penggunaan internet untuk melakukan pembelian didukung.

2. Ada hubungan yang signifikan antara norma subjektif dan intensi penggunaan internet untuk melakukan pembelian $(\beta=$ 0,294; S.E. $=0,178 ;$ C.R. $=1,658$ ) atau $P=$ $0,097<0,10$. Temuan ini menjelaskan bahwa semakin tinggi tingkat norma subjektif maka akan semakin tinggi juga tingkat intensi penggunaan internet untuk melakukan pembelian. Dengan demikian hipotesis yang menyatakan bahwa norma subjektif berpengaruh

Tabel 2. Hasil Uji Hipotesis Sebelum Adanya Moderasi

\begin{tabular}{|c|c|c|c|c|c|c|}
\hline & & & Estimate & S.E. & C.R. & $P$ \\
\hline Sikap & $\rightarrow$ & $\begin{array}{l}\text { Intensi penggunaan } \\
\text { internet untuk pencarian } \\
\text { informasi }\end{array}$ & $-0,160$ & 0,094 & $-1,705$ & 0,088 \\
\hline Norma subjektif & $\rightarrow$ & $\begin{array}{l}\text { Intensi penggunaan } \\
\text { internet untuk pencarian } \\
\text { informasi }\end{array}$ & 0,294 & 0,178 & 1,658 & 0,097 \\
\hline $\begin{array}{l}\text { Kontrol perilaku yang } \\
\text { dirasakan }\end{array}$ & $\rightarrow$ & $\begin{array}{l}\text { Intensi penggunaan } \\
\text { internet untuk pencarian } \\
\text { informasi }\end{array}$ & $-1,117$ & 0,510 & $-2,191$ & 0,028 \\
\hline $\begin{array}{l}\text { Pengalaman belanja } \\
\text { online }\end{array}$ & $\rightarrow$ & $\begin{array}{l}\text { Intensi penggunaan } \\
\text { internet untuk pencarian } \\
\text { informasi }\end{array}$ & 0,100 & 0,135 & 0,743 & 0,458 \\
\hline Kepercayaan & $\rightarrow$ & $\begin{array}{l}\text { Intensi penggunaan } \\
\text { internet untuk pencarian } \\
\text { informasi }\end{array}$ & 1,008 & 0,218 & 4,622 & 0,000 \\
\hline
\end{tabular}


signifikan terhadap intensi penggunaan internet untuk melakukan pembelian didukung.

3. Ada hubungan yang signifikan antara kontrol perilaku yang dirasakan dan intensi penggunaan internet untuk melakukan pembelian $(\beta=-1,117$ atau bernilai negatif; S.E. $=0,510 ; C . R .=-2,191$ ) atau $P=0,028<0,05$. Temuan ini menjelaskan bahwa semakin rendah kontrol perilaku yang dirasakan dari individu itu sendiri maka akan semakin tinggi tingkat intensi penggunaan internet untuk melakukan pembelian. Dengan demikian hipotesis yang menyatakan bahwa kontrol perilaku yang dirasakan berpengaruh signifikan terhadap intensi penggunaan internet untuk melakukan pembelian didukung.

4. Ada hubungan yang tidak signifikan antara pengalaman belanja online dan intensi penggunaan internet untuk melakukan pembelian $(\beta=0,100 ;$ S.E. $=$ 0,$218 ; C . R .=4,622$ ) atau $P=0,458>0,10$. Temuan ini menjelaskan bahwa pengalaman belanja online tidak memiliki pengaruh baik positif maupun negatif terhadap intensi penggunaan internet untuk melakukan pembelian. Dengan demikian hipotesis yang menyatakan bahwa pengalaman belanja online berpengaruh signifikan terhadap intensi penggunaan internet untuk melakukan pembelian tidak didukung.

5. Ada hubungan yang signifikan antara kepercayaan dan intensi penggunaan internet untuk melakukan pembelian $(\beta=$ 1,008; S.E. $=0,218 ;$ C.R. $=4,622)$ atau $P=$ $0,000<0,01$. Temuan ini menjelaskan bahwa semakin tinggi tingkat kepercayaan dari individu itu sendiri maka akan semakin tinggi tingkat intensi penggunaan internet untuk melakukan pembelian. Dengan demikian hipotesis yang menyatakan bahwa kepercayaan berpengaruh signifikan terhadap intensi penggunaan internet untuk melakukan pembelian didukung.

Variabel moderator dalam penelitian ini adalah intensi penggunaan internet untuk pencarian informasi dengan skala nominal berdasarkan tingkat intensitas penggunaan untuk pencarian informasinya, sehingga uji moderasi dilakukan dengan membuat split sampel. Responden yang memiliki nilai intensi penggunaan internet untuk pencarian informasi di atas rata-rata dikelompokan sebagai kelompok intensitas pencarian tinggi, sedangkan responden dengan nilai intensi penggunaan internet untuk pencarian informasi di bawah rata-rata dikelompokan sebagai kelompok intensitas pencarian rendah, karena variabel moderator bersifat degree, maka uji moderasi menggunakan metode uji multigroup.

Untuk menguji apakah model constrained dengan model unconstrained berbeda secara signifikan maka digunakan uji perbandingan nilai chi square tabel $(\chi 2)$ dengan selisih nilai chi square hitung $(\Delta \times 2)$. Jika chi square tabel $(x 2)>$ selisih chi square hitung $(\Delta \times 2)$ maka model constrained diindikasikan berbeda secara signifikan dengan model unconstrained (Marsh dan Scalas, 2010).

Tabel 3 didapat hasil pengujian multigroup setelah dimoderasi dengan variabel intensi penggunaan internet untuk pencarian informasi yang menunjukkan bahwa pada kelompok intensitas pencarian tinggi pada sikap berpengaruh negatif dan 
Tabel 3. Hasil Uji Hipotesis Setelah Dimoderasi

\begin{tabular}{|c|c|c|c|c|c|c|c|c|c|}
\hline & & \multicolumn{4}{|c|}{ Intensitas Pencarian Tinggi } & \multicolumn{4}{|c|}{ Intensitas Pencarian Rendah } \\
\hline & & Estimate & S.E. & C.R. & $P$ & Estimate & S.E. & C.R. & $\mathrm{P}$ \\
\hline Sikap & $\rightarrow$ Intensi pembelian &,- 303 & 134 & $-2,256$ & ,024 & ,008 & 120 & ,063 & 950 \\
\hline Norma subjektif & $\rightarrow$ Intensi pembelian &, 074 & 175 & ,423 & 672 & ,668 &, 360 & 1,858 &, 063 \\
\hline $\begin{array}{l}\text { Kontrol perilaku } \\
\text { yang dirasakan }\end{array}$ & $\rightarrow$ Intensi pembelian & $-2,061$ &, 726 & $-2,840$ &, 005 &,- 483 & ,652 &,- 740 & ,459 \\
\hline $\begin{array}{l}\text { Pengalaman } \\
\text { belanja online }\end{array}$ & $\rightarrow$ Intensi pembelian & ,317 & 161 & 1,969 &, 049 &,- 200 & ,265 &,- 755 & ,450 \\
\hline Kepercayaan & $\rightarrow$ Intensi pembelian & 1,264 & ,313 & 4,040 &, 000 &, 597 & ,268 & 2,223 &, 026 \\
\hline $\begin{array}{l}\text { Selisih chi squar } \\
\text { Selisih } d f(\Delta d f)= \\
\text { chi square tabel } \\
\text { chi square tabel } \\
\text { Model Constrain }\end{array}$ & $\begin{array}{l}\text { tung }(\Delta \times 2)=642,951- \\
8-644=4 \\
0,05)=9,488 \\
>\text { selisih chi square hit } \\
\text { erbeda signifikan deng }\end{array}$ & $, 019=3,93$ & & & & & & & \\
\hline
\end{tabular}

signifikan terhadap intensi penggunaan internet untuk melakukan pembelian ketika dimoderasi oleh intensi penggunaan internet untuk pencarian informasi ( $\beta=-0,303$ atau bernilai negatif ; S.E. =0,134; C.R. $=-2,256$ ) atau $P=0,024<0,05$. Pada kelompok intensitas pencarian rendah sikap berpengaruh positif tetapi tidak signifikan terhadap intensi penggunaan internet untuk melakukan pembelian ketika dimoderasi oleh intensi penggunaan internet untuk pencarian informasi $(\beta=0,008$; S.E. $=0,120 ;$ C.R. $=$ 0,063 ) atau $P=0,950>0,1$.

Hasil uji regresi multigroup pada kelompok intensitas pencarian tinggi dan kelompok intensitas pencarian informasi rendah diperoleh fakta bahwa terdapat perbedaan pengaruh sikap terhadap intensi penggunaan internet untuk melakukan pembelian yang dimoderasi oleh intensi penggunaan internet untuk pencarian informasi. Hal tersebut didukung fakta bahwa chi square tabel $(\chi 2)>$ selisih chi square hitung $(\Delta \chi 2)$, sehingga pengaruh sikap terhadap intensi penggunaan internet untuk melakukan pembelian yang dimoderasi oleh intensi penggunaan internet untuk pencarian informasi diindikasi berbeda secara signifikan, atau dengan kata lain bahwa intensi penggunaan internet untuk pencarian informasi memoderasi pengaruh sikap terhadap intensi penggunaan internet untuk melakukan pembelian pada kelompok intensitas pencarian tinggi. Dengan demikian hipotesis yang menyatakan bahwa sikap berpengaruh signifikan terhadap intensi penggunaan internet untuk melakukan pembelian yang dimoderasi oleh intensi penggunaan internet untuk pencarian informasi didukung.

Pengujian multigroup setelah dimoderasi dengan variabel intensi penggunaan internet untuk pencarian informasi yang menunjukkan bahwa pada kelompok intensitas pencarian tinggi norma subjektif memiliki pengaruh positif tetapi tidak signifikan terhadap intensi penggunaan internet untuk melakukan pembelian ketika dimoderasi oleh intensi penggunaan internet untuk pencarian informasi $(\beta=0,074 ; \mathrm{S}$.E. $=$ 0,$175 ; C . R .=0,423$ ) atau $P=0,672>0,1$. Pada kelompok intensitas pencarian rendah norma subjektif berpengaruh positif dan signifikan terhadap intensi penggunaan internet untuk 
melakukan pembelian ketika dimoderasi oleh intensi penggunaan internet untuk pencarian informasi $(\beta=0,668$; S.E. $=0,360 ;$ C.R. $=$ 1,858 ) atau $P=0,063<0,1$.

Hasil uji regresi multigroup pada kelompok intensitas pencarian tinggi dan kelompok intensitas pencarian informasi rendah diperoleh fakta bahwa terdapat perbedaan pengaruh norma subjektif terhadap intensi penggunaan internet untuk melakukan pembelian yang dimoderasi oleh intensi penggunaan internet untuk pencarian informasi. Hal tersebut didukung fakta bahwa chi square tabel $(x 2)>$ selisih chi square hitung $(\Delta \chi 2)$, sehingga pengaruh norma subjektif terhadap intensi penggunaan internet untuk melakukan pembelian yang dimoderasi oleh intensi penggunaan internet untuk pencarian informasi diindikasi berbeda secara signifikan, atau dengan kata lain bahwa intensi penggunaan internet untuk pencarian informasi memoderasi pengaruh norma subjektif terhadap intensi penggunaan internet untuk melakukan pembelian pada kelompok intensitas pencarian rendah. Dengan demikian hipotesis yang menyatakan bahwa norma subjektif berpengaruh signifikan terhadap intensi penggunaan internet untuk melakukan pembelian yang dimoderasi oleh intensi penggunaan internet untuk pencarian informasi didukung.

Hasil pengujian multigroup setelah dimoderasi dengan variabel intensi penggunaan internet untuk pencarian informasi yang menunjukkan bahwa pada kelompok intensitas pencarian tinggi kontrol perilaku yang dirasakan memiliki pengaruh negatif dan signifikan terhadap intensi penggunaan internet untuk melakukan pembelian ketika dimoderasi oleh intensi penggunaan internet untuk pencarian informasi ( $\beta=-2,061$ atau bernilai negatif; S.E. $=0,726 ; C . R .=-2,840$ ) atau $P=0,005<$ 0,05 . Pada kelompok intensitas pencarian rendah kontrol perilaku yang dirasakan berpengaruh negatif dan tidak signifikan terhadap intensi penggunaan internet untuk melakukan pembelian ketika dimoderasi oleh intensi penggunaan internet untuk pencarian informasi ( $\beta=-0,483$ atau bernilai negatif; S.E. $=0,652 ; C . R .=-0,740$ ) atau $P=0,459>$ 0,1 .

Hasil uji regresi multigroup pada kelompok intensitas pencarian tinggi dan kelompok intensitas pencarian informasi rendah diperoleh fakta bahwa terdapat perbedaan pengaruh kontrol perilaku yang dirasakan terhadap intensi penggunaan internet untuk melakukan pembelian yang dimoderasi oleh intensi penggunaan internet untuk pencarian informasi. Hal tersebut didukung fakta bahwa chi square tabel ( $\chi 2)>$ selisih chi square hitung $(\Delta \chi 2)$, sehingga pengaruh kontrol perilaku yang dirasakan terhadap intensi penggunaan internet untuk melakukan pembelian yang dimoderasi oleh intensi penggunaan internet untuk pencarian informasi diindikasi berbeda secara signifikan, atau dengan kata lain bahwa intensi penggunaan internet untuk pencarian informasi memoderasi pengaruh kontrol perilaku yang dirasakan terhadap intensi penggunaan internet untuk melakukan pembelian pada kelompok intensitas pencarian tinggi. Dengan demikian hipotesis yang menyatakan bahwa kontrol perilaku yang dirasakan berpengaruh signifikan terhadap intensi penggunaan internet untuk melakukan pembelian yang dimoderasi oleh 
intensi penggunaan internet untuk pencarian informasi didukung.

Tabel 3 juga diperoleh hasil pengujian multigroup setelah dimoderasi dengan variabel intensi penggunaan internet untuk pencarian informasi yang menunjukkan bahwa pada kelompok intensitas pencarian tinggi pengalaman belanja online berpengaruh positif dan signifikan terhadap intensi penggunaan internet untuk melakukan pembelian ketika dimoderasi oleh intensi penggunaan internet untuk pencarian informasi ( $\beta=0,317 ;$ S.E. $=0,161 ;$ C.R. $=1,969$ ) atau $P=0,049<0,05$. Pada kelompok intensitas pencarian rendah pengalaman belanja online berpengaruh negatif dan tidak signifikan terhadap intensi penggunaan internet untuk melakukan pembelian ketika dimoderasi oleh intensi penggunaan internet untuk pencarian informasi ( $\beta=-0,200$ atau bernilai negatif; S.E. $=0,265 ;$ C.R. $=-0,755$ ) atau $P=0,450>0,1$.

Hasil uji regresi multigroup pada kelompok intensitas pencarian tinggi dan kelompok intensitas pencarian informasi rendah diperoleh fakta bahwa terdapat perbedaan pengaruh pengalaman belanja online terhadap intensi penggunaan internet untuk melakukan pembelian yang dimoderasi oleh intensi penggunaan internet untuk pencarian informasi. Hal tersebut didukung fakta bahwa chi square tabel $(x 2)>$ selisih chi square hitung $(\Delta \times 2)$, sehingga pengaruh pengalaman belanja online terhadap intensi penggunaan internet untuk melakukan pembelian yang dimoderasi oleh intensi penggunaan internet untuk pencarian informasi diindikasi berbeda secara signifikan, atau dengan kata lain bahwa intensi penggunaan internet untuk pencarian informasi memoderasi pengaruh pengalaman belanja online terhadap intensi penggunaan internet untuk melakukan pembelian pada kelompok intensitas pencarian tinggi. Dengan demikian hipotesis yang menyatakan bahwa pengalaman belanja online berpengaruh signifikan terhadap intensi penggunaan internet untuk melakukan pembelian yang dimoderasi oleh intensi penggunaan internet untuk pencarian informasi didukung.

Hasil pengujian multigroup setelah dimoderasi dengan variabel intensi penggunaan internet untuk pencarian informasi yang menunjukkan bahwa pada kelompok intensitas pencarian tinggi kepercayaan berpengaruh positif dan signifikan terhadap intensi penggunaan internet untuk melakukan pembelian ketika dimoderasi oleh intensi penggunaan internet untuk pencarian informasi ( $\beta=1,264$; S.E. = 0,313; C.R. $=4,040$ ) atau $P=0,000<0,001$. Pada kelompok intensitas pencarian rendah kepercayaan berpengaruh positif dan signifikan terhadap intensi penggunaan internet untuk melakukan pembelian ketika dimoderasi oleh intensi penggunaan internet untuk pencarian informasi ( $\beta=0,597$; S.E. = 0,268 ; C.R. $=2,223$ ) atau $P=0,026<0,05$.

Hasil uji regresi multigroup pada kelompok intensitas pencarian tinggi dan kelompok intensitas pencarian informasi rendah diperoleh fakta bahwa terdapat perbedaan pengaruh tingkat kepercayaan individu terhadap intensi penggunaan internet untuk melakukan pembelian yang dimoderasi oleh intensi penggunaan internet untuk pencarian informasi. Hal tersebut didukung fakta bahwa chi square tabel $(\chi 2)>$ selisih chi square hitung $(\Delta \chi 2)$, sehingga 
pengaruh tingkat kepercayaan terhadap intensi penggunaan internet untuk melakukan pembelian yang dimoderasi oleh intensi penggunaan internet untuk pencarian informasi diindikasi berbeda secara signifikan, atau dengan kata lain bahwa intensi penggunaan internet untuk pencarian informasi memoderasi pengaruh pengalaman belanja online terhadap intensi penggunaan internet untuk melakukan pembelian pada kelompok intensitas pencarian tinggi dan kelompok intensitas pencarian rendah. Dengan demikian hipotesis yang menyatakan bahwa kepercayaan berpengaruh signifikan terhadap intensi penggunaan internet untuk melakukan pembelian yang dimoderasi oleh intensi penggunaan internet untuk pencarian informasi didukung.

\section{SIMPULAN}

Berdasarkan analisis dan pembahasan dari rumusan masalah yang diangkat dalam penelitian ini, maka dapat disimpulkan sebagai berikut : Faktor-faktor penentu niat seperti sikap, norma subjektif, kontrol perilaku yang dirasakan, dan kepercayaan terbukti berpengaruh secara signifikan terhadap intensi penggunaan internet untuk melakukan pembelian, sedangkan salah satu faktor penentu niat yakni pengalaman belanja online tidak terbukti berpengaruh secara signifikan terhadap intensi penggunaan internet untuk melakukan pembelian dan Intensitas penggunaan internet untuk pencarian informasi terbukti mampu memoderasi faktor-faktor penentu niat seperti sikap, norma subjektif, kontrol perilaku yang dirasakan, pengalaman belanja online, dan kepercayaan terhadap intensi penggunaan internet untuk melakukan pembelian.

\section{DAFTAR PUSTAKA}

Ajzen, I. (1991). The Theory of Planned Behavior. Organizational Behavior and Decision Processes. 50, 179-211.

Dai, B., S. Forsythe, dan Wi-Suk Kwon. (2014). The Impact of Online Shopping Experience On Risk Perceptions And Online Purchase Intentions: Does Product Category Matter? Journal of Electronic Commerce Research. 15(1), 13-24.

Ferdinand, A. (2002). Structural Equation Modelling dalam Penelitian Manajemen. Semarang: FE UNDIP.

Fishbein, M. dan I. Ajzen. (1975). Belief, attitude, intention and behaviour: An introduction to theory and research: Addison-Wesley.

Forsythe S.M., dan B Shi. (2003). Consumer Patronage and Risk Perceptions in Internet Shopping. Journal of Business Research. 56, 867-875.

Ghozali, I. (2008). Model Persamaan Struktural Konsep dan Aplikasi dengan Program Amos 16.0. Semarang: FE UNDIP.

Javadi, M.H.M., H.R. Dolatabadi, M. Nourbakhsh, A. Poursaeedi, dan A.R. Asaddollahi. (2012). An Analysis Factor Affecting on Online Shopping Behavior of Consumers. International Journal of Marketing Studies. 4(5), 81-98.

Jusoh, Z.Md., \& Ling, G.H. (2012). Factors Influencing Consumers' Attitude Towards E-Commerce Purchase Through Online Shopping. International Journal of Humanities and Social Science. 2(4), 223230.

Kim, J.I., H.C. Lee, dan H.J. Kim. (2004). Factors Affecting Online Search Intention 
and Online Purchase Intention. Seoul Journal of Business. 10(2), 27-48.

Lin, Hsiu-Fen. (2007). Predicting Consumer Intentions to Shop Online: An empirical test of comppeting theories. Electronic Commerce Research and Applications. 6(4), 433-442.

Ling, K.C., L.T. Chai, dan T.H. Piew. (2010). The Effects of Shopping Orientations, Online Trust and Prior Online Purchase Experience toward Customers' Online Purchase Intention. International Business Research. 3(3), 63-76.

Liu, C., J.T. Marchewka, J. Lu, dan Chun-Sheng Yu. (2005). Beyond concern-a privacytrust-behavioral intention model of electronic commerce. Information and Management. 42, 289-304.

Marsh, H. W., Scalas, L. F. (2010). Longitudinal Tests of Competing Factor Structures for the Rosenberg Self-Esteem Scale: Traits, Ephemeral Artifacts, and Stable Response Styles. Psychological Assessment, 22(2), 366-381.

Rianto, Y., R. Lumanto, dan S. Meiningsih. (2013). Potret Belanja Online di Indonesia (Kasus: Jabodetabek, Bandung, dan
Jogja). Jakarta Pusat: Pusat Data dan Sarana Informatika Kementerian Komunikasi dan Informatika.

Santoso, S. (2015). Amos 22 untuk Structural Equation Modelling. Jakarta: PT. Elex Media Komputindo, Kompas Gramedia Building.

Shim, S., M.A. Eastlick, S.L. Lotz, dan P. Warrington. (2001). An online prepurchase intentions model: The role of intention to search. Journal of Retailing. 77, 397-416.

Velarde, V.D.V. (2012). Determinants of online purchasing behavior: An empirical investigation using an extension of the Theory of Planned Behavior. Malaysia: Aarhus University.

Yannopoulos, P. (2011). Impact of the Internet on Marketing Strategy Formulation. International Journal of Business and Social Science. 2(18), 1-7.

Yulihasri, Md.A. Islam, dan K.A.K. Daud. (2011). Factors that Influence Customers' Buying Intention on Shopping Online. International Journal of Marketing Studies. 3(1), 128-139. 